УДК 911.52

https://doi.org/10.15407/ugz2017.03.021

\title{
I.A. Байдіков
}

Інститут географії Національної академії наук України, Київ

\section{СУЧАСНА ЛАНДШАФТНА СТРУКТУРА ТЕРИТОРІЇ ХЕРСОНСЬКОЇ ОБЛАСТІ ЯК ОСНОВА ДЛЯ УКЛАДАННЯ СЕРЕДНЬОМАСШТАБНОЇ КАРТИ ЛАНДШАФТНИХ КОМПЛЕКСІВ РЕГІОНУ}

\begin{abstract}
Мета публікації - висвітлення особливостей ландшафтів Херсонської області з урахуванням їі фізико-географічного (ландшафтного) районування як основи для укладання карти ландшафтних комплексів на іiі територію. Структурна будова фізико-географічних країв досліджувалася з урахуванням особливостей ландшафтів на рівні місцевостей та окремих ландшафтних комплексів, включно з азональними: межиріч (низовин), приморських рівнин, надзаплавних терас, річкових заплав, яружно-балкових, подових комплексів, морських кіс та островів. Укладено карту ландшафтних комплексів досліджуваної території на рівні місцевостей.
\end{abstract}

Ключові слова: ландшафтна структура; ландшафтний комплекс; ландшафтний край; карта ландшафтних комплексів; Херсонська область.

\section{I.A. Baydikov}

Institute of geography of the National Academy of Sciences of Ukraine, Kyiv MODERN LANDSCAPE STRUCTURE OF THE TERRITORY OF THE KHERSON AREA AS A BASIS FOR THE INTRODUCTION OF THE MIDDLE-SCALE PLAN OF LANDSCAPE COMPLEXES OF THE REGION *

The purpose of the publication is to highlight the landscape features of the Kherson region, taking into account its physical and geographical (landscape) zoning as the basis for laying the map of landscape complexes on its territory. The structure of the physical and geographical regions was studied taking into account the features of the landscapes at the level of localities and individual landscape complexes, including the azonal ones: the interfluves (lowlands), the coastal plains, the floodplain terraces, the river flood plains, the lagoon-beam, submarine complexes, the sea bass and the islands. A map of the landscape complexes of the study area at the local level is plotted.

Keywords: landscape structure; landscape complex; landscape edge; map of landscape complexes; Kherson region.

\section{Ветуп}

Ландшафтна структура будь-якої території чи акваторії являє собою складну багатоаспектну систему, що поєднує різнорангові ландшафтні комплекси. Знання про ландшафти, їх просторову диференціацію є основою фізико-географічного районування певної території. Вони набувають особливого значення у контексті розроблення та впровадження ландшафтно-планувальних заходів.

У 2003 р. розроблено удосконалену схему фізико-географічного районування території України [3], основою для укладання якої є ландшафтно-генетичний принцип, обгрунтований авторами у попередні роки [2], та карта ландшафтів, укладена за цим принципом $[3,6]$.

Відповідно до завдань теми відділу ландшаф-

\footnotetext{
${ }^{*}$ Статтю підготовлено за результатами досліджень у рамках науково-дослідної теми “Методологія середньомасштабного геоінформаційного картографування ландшафтів України", що виконувалася відділом ландшафтознавства Інституту географії НАН України в 2010-2016 роках.
}

\section{() I.A. Байдіков, 2017}

тознавства Інституту географії НАН України №3 «Методологія середньомасштабного геоінформаційного картографування ландшафтів України» були проведені роботи щодо укладання карти ландшафтних комплексів, у т.ч. і на територію Херсонської області, у масштабі 1:500 000 як складової карти ландшафтних комплексів України.

В основу цього дослідження покладено роботи, присвячені вивченню структури ландшафтів території України $[2,3,5,6]$, картографічні матеріали, як окремо видані карти ${ }^{1,2,3}$, так і вміщені в Національному атласі України: Геологічна будова, Четвертинні відклади, Грунти, Рослинність,

\footnotetext{
${ }^{1}$ Геоморфологическая карта Украинской ССР и Молдавской ССР / И.Л. Соколовский, Б.Д. Возгрин, Г.Г. Грузман, И.М. Рослый. Масштаб 1:1 000 000, 1979.

${ }^{2}$ Карта четвертинних відкладів / Б.Д. Возгрін, Г.І. Педанюк, Л.О. Демехін, В.М. Соловицький. Масштаб: 1:1 000 000, 2000.

${ }^{3}$ Карта растительности Украинской ССР / Г.И. Билык, Ю.Р. Шеляг-Сосонко, Т.Л. Андриенко и др. Масштаб 1:1500 000.
} 
Ландшафти, Фізико-географічне районування 4 . Частково використано матеріали 3 [1] та власних польових ландшафтознавчих досліджень автора.

\section{Виклад основного матеріалу}

Херсонська область розташована в межах Причорноморської низовини, на півдні омивається водами Чорного та Азовського морів. Ї̈̈ поверхня - слабохвиляста рівнина, полого нахилена у південному напрямі. У межах Херсонської області представлені лесові пластово-акумулятивні, пластово-денудаційні та алювіальні (приморські) низовини. Характерними елементами рельєфу $є$ поди та балки, невеликі півострови та довгі вузькі піщані коси, також у межах області є кілька островів; з аквальних комплексів - затоки, лимани, солоні озера.

Клімат помірно континентальний з м'якою малосніжною зимою та спекотним посушливим літом.

Серед зональних типів грунтів переважають чорноземи південні малогумусні; далі на південь - чорноземи солонцюваті та каштанові солонцюваті грунти у комплексі з солонцями; серед інтразональних - лучно-чорноземні й дернові глейові грунти.

Природна степова рослинність збереглася переважно в долинах річок, на крутих схилах балок та у межах об'єктів природно-заповідного фонду області.

Херсонська область знаходиться у межах двох підзон степової зони - середньостепової (Причорноморський фізико-географічний край) та південностепової, або сухостепової (Причорноморсько-Приазовський край) (рис. 1)

Ландшафти Херсонської області відзначаються різноманітністю структури, що поєднує суходільні (включно із прибережно-морськими) та аквальні ландшафтні комплекси. Основними $€$ низовинні ландшафтні комплекси межиріч та приморських рівнин, що поділяються, відповідно до фізико-географічного (ландшафтного) районування, на середньо- та південностепові (сухостепові). Вони урізноманітнені ландшафтними комплексами надзаплавних терас, а також азональними річкових заплав, яружно-балковими та подовими, щільність і поширеність яких змінюються залежно від зміни літооснови та дренованості території області 3 північного сходу на

\footnotetext{
${ }^{4}$ Національний атлас України. К., 2007. С. 108-109, 114$115,188-189,222-224,228-229$.
}

південний захід. Важливими елементами регіональної ландшафтної структури $\epsilon$ азональні ландшафтні комплекси лиманів, морських узбереж i кіс, островів і відмілин (рис. 2).

\section{Середньостепова підзона.}

\section{Причорноморський середньостеповий край}

Причорноморський середньостеповий край охоплює північну частину Причорноморської низовини, яка у геоструктурному відношенні відповідає північному крилу Причорноморської западини. Це, разом із температурними показниками та умовами зволоження, значною мірою зумовило особливості ландшафтної структури краю [2].

На Херсонщині у межах краю виділяють дві фізико-географічні області: Бузько-Дніпровську низовинну та Дніпровсько-Молочанську низовинну. Значення домінантних ландшафтів для Причорноморського середньостепового краю мають місцевості межирічних низовин. Структурно вони поділяються на пластово-акумулятивні та пластово-денудаційні низовини.

Пластово-акумулятивні низовини під типчаково-ковиловою рослинністю степів північних поширені у південній частині Дніпровсько-Молочанської низовинної області. Низовини сформувалися на осадових породах центральної частини Причорноморської низовини. Вони характеризуються плоскою субгоризонтальною поверхнею, що відрізняється незначним ступенем розчленування, який збільшується у напрямі до долини Дніпра. В рельєфі представлені просадкові форми.

Серед зональних типів грунтів представлені чорноземи південні малогумусні та темно-каштанові грунти, в т.ч. солонцюваті. Зональні грунти у межах від'ємних форм рельєфу - балок та подів - поширені у комплексі з азональними лучно-чорноземними осолоділими та глейовими солонцювато-осолоділими грунтами.

Природна рослинність фрагментарно збереглася на схилах балок та представлена типчаково-ковиловою рослинністю степів північних та подових луків.

Пластово-денудаційні низовини під типчаково-ковиловою рослинністю степів північних та подових луків, характерні для Бузько-Дніпровської низовинної області, сформувалися на осадових породах північної частини Причорноморської низовини. Поверхня низовин переважно плоска, 


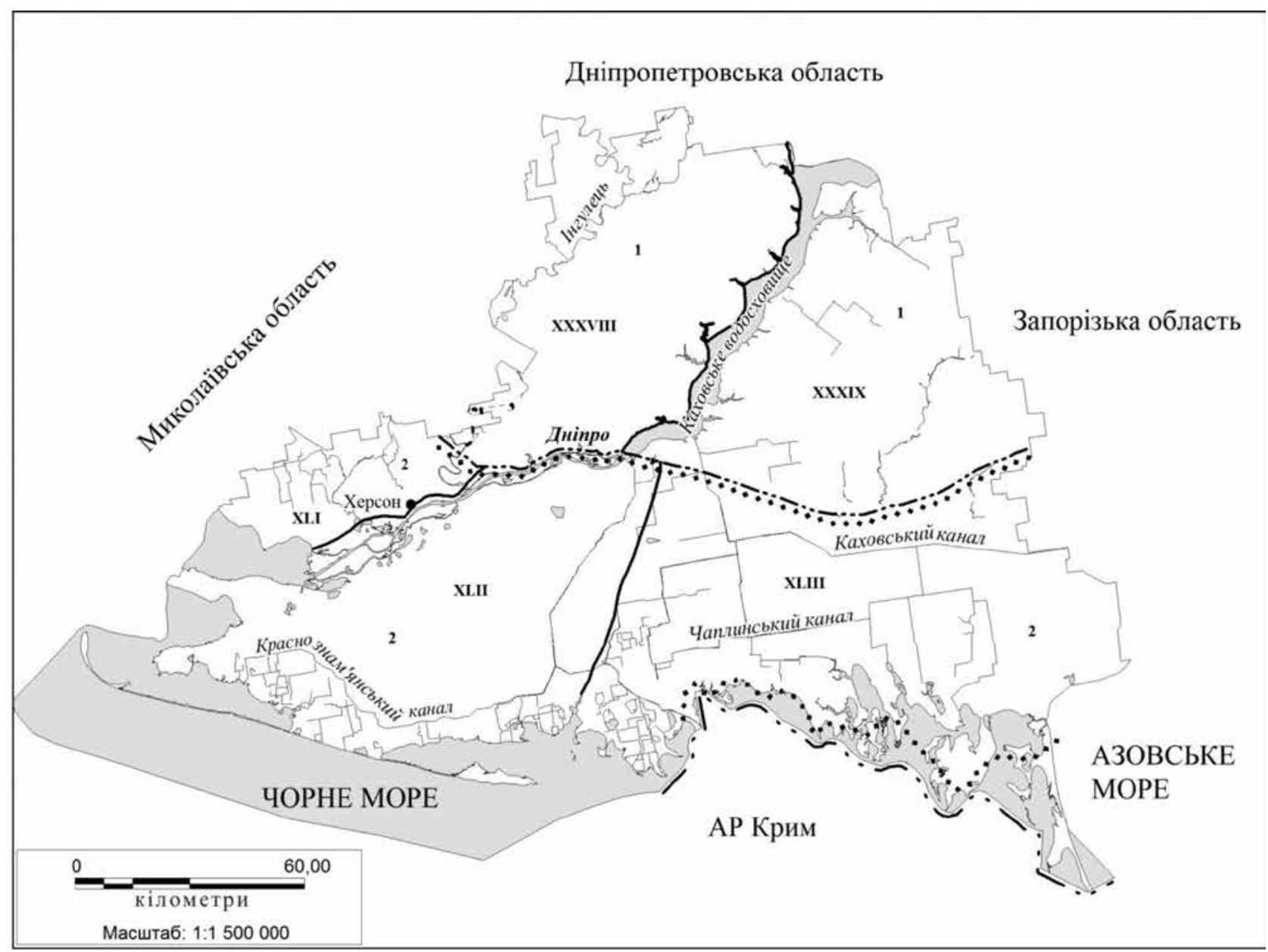

Середньостепова підзона

\section{1. Причорноморський край}

ХХХИІІІ Бузько-Дніпровська низовинна область

ХХХІХ Дніпровсько-Молочанська низовинна область

\section{СТЕПОВА 3ОНА}

Південностепова (сухостепова) підзона

\section{2. Причорноморсько-Приазовський край}

ХLI Нижньобузько-Дніпровська низовинна область

XLII Нижньодніпровська терасово- дельтова низовинна область

ХLIII Присивасько-Приазовська низовинна область

Межі одиниць фізико-географічного районування

\footnotetext{
-.--.. - фізико-географічних підзон

...... - фізико-географічних країв
}

—— - фізико-географічних областей

Puc. 1. Схема фізико-географічного районування території Херсонської області [4].

ступінь розчленування варіює від слабо- до дуже розчленованої (сильно розчленовані низовини, що мають похил в бік Дніпра). В рельєфі представлені такі форми рельєфу: ерозійні (водно-ерозійні): річкові долини (в комплексі з акумулятивними заплавами та терасами), яри, балки, а також просадкові: поди, степові блюдця.

Зональними типами грунтів $є$ чорноземи звичайні та південні малогумусні й темнокаштанові солонцюваті, що характерні для низовин, а також надзаплавних терас. Азональні грунти (лучно-чорноземні осолоділі глеюваті, глейові солонцюватоосолоділі та дернові) властиві переважно інтразональним ландшафтним комплексам - річковим долинам (заплави), балкам, подам.

Територія Причорноморського середньостепового краю відзначається значним сільськогосподарським освоєнням. Відповідно, на більшій 


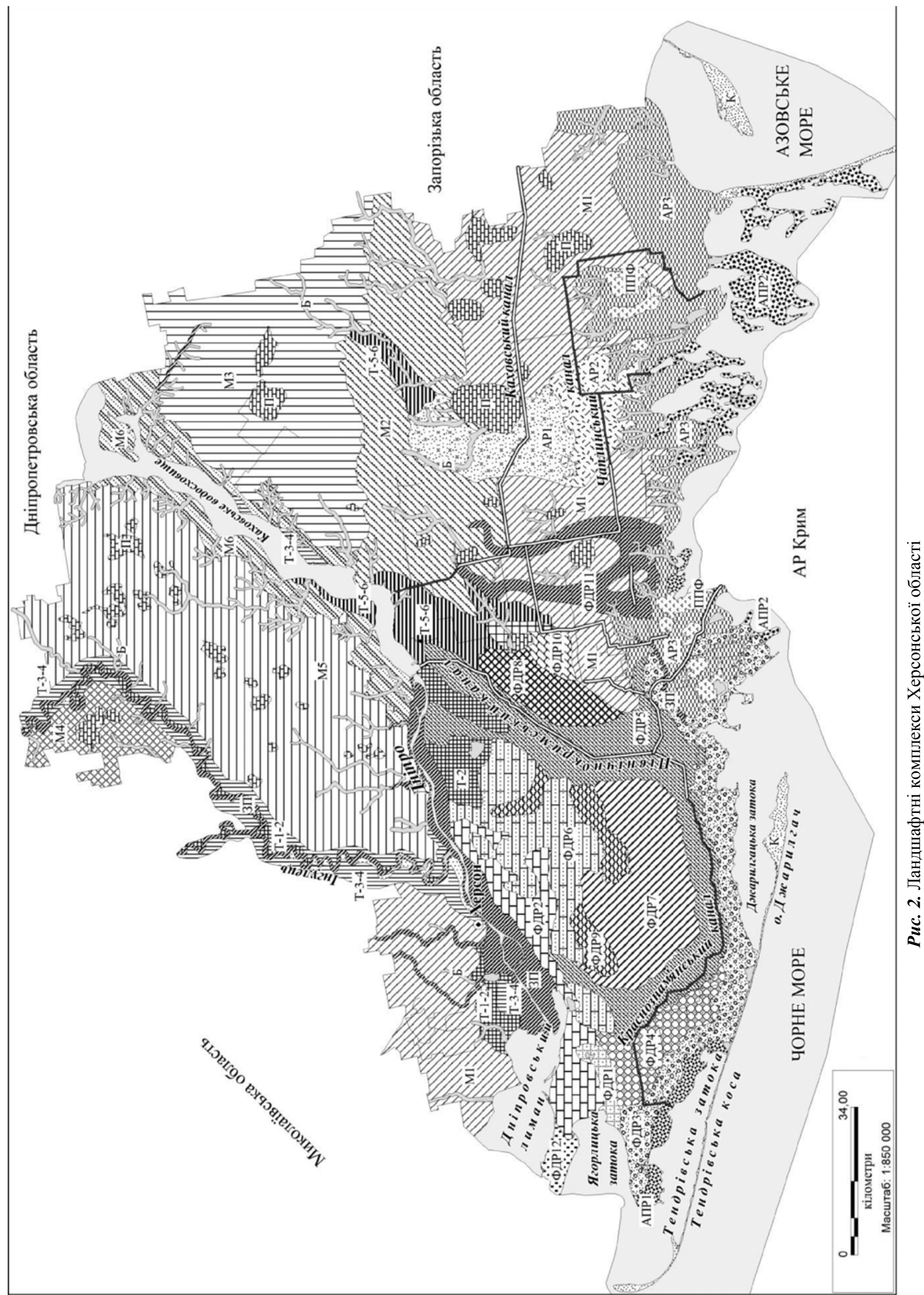


Легенда до рис. 2. Ландшафтні комплекси Херсонської області

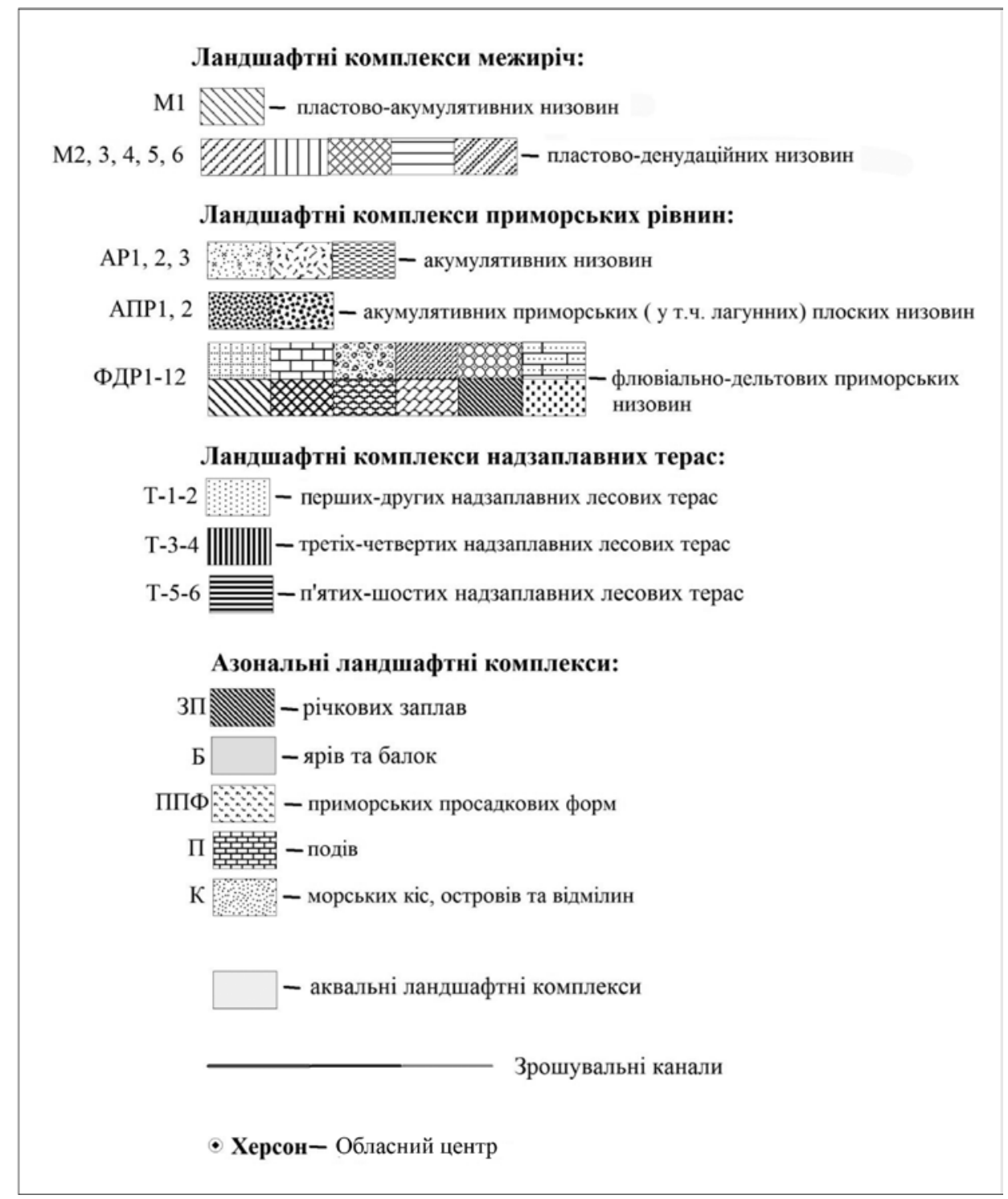

частині території Херсонської області поширені орні угіддя, сади та пасовища (збиті і дуже збиті). Основними проявами природно-антропогенних процесів $€$ площинна та яружна ерозія, зсуви, просідання порід, засолення. Антропогенні впливи зумовили деградацію природного рослинного покриву та його фрагментарне збереження лише в місцях важко- та недоступних для господарського використання - крутосхили долинно-терасових та яружно-балкових комплексів, поди (частково).

Південностепова (сухостепова) підзона Причорноморсько-Приазовський південностеповий (сухостеповий) край

Територіально край охоплює центральну та південну частини Причорноморської низовини і у геоструктурному відношенні приурочений до осьової частини Причорноморської западини [6].

У межах краю, на території Херсонської області, виділяють Нижньобузько-Дніпровську низовинну, Нижньодніпровську терасово-дельтову низовинну та Присивасько-Приазовську низовинну фізико-географічні області. Домінантні ландшафти тут також представлені місцевостями межирічних низовин, які структурно поділяються на пластово-акумулятивні розчленовані і безстічні западинно-подові та на акумулятивні (в т.ч. приморські) низовини.

Пластово-акумулятивні низовини під типчаково-ковиловою рослинністю степів північних ma південних (сухих) характерні для Нижньобузько-Дніпровської та Присивасько-Приазовської 
низовинних областей. Сформувалися вони на осадових породах в умовах переважаючих опускань Причорноморської западини.

Поверхня плоска, розчленована річковими долинами та балками; ступінь розчленування зменшується в південному напрямі, внаслідок чого їх поверхня в південній частині нерозчленована (слаборозчленована) і відзначається переважанням у рельєфі просадкових форм - безстічні западинно-подові низовини.

Грунтовий покрив пластово-акумулятивних низовин представлений зональними чорноземами південними малогумусними солонцюватими та осолоділими і темно-каштановими залишковосолонцюватими грунтами. Азональні грунти лучно-чорноземні та лучно-темнокаштанові в комплексі з солонцями і солончаками, глейовими грунтами і глеєсолодями подів.

Внаслідок розораності території низовин та наявності у їх межах значних площ дигресивних пасовищ природна типчаково-ковилова рослинність степів, а також рослинність подових луків представлена лише фрагментарно - в місцях, непридатних для господарського використання.

Акумулятивні низовини сформувалися на осадових породах осьової частини Причорноморської низовини внаслідок спільної дії рік і морів. Вони поділяються на акумулятивні, в т.ч. приморські, та флювіально-дельтові низовини і характерні для Нижньодніпровської терасово-дельтової та Присивасько-Приазовської низовинної областей.

Акумулятивні низовини під типчаково-ковиловою рослинністю степів південних (сухих) та подовими луками сформувалися на еолово-делювіальних і елювіальних породах, мають плоску субгоризонтальну поверхню, слабо розчленовані балками і ускладнені просадковими формами - переважно подами та степовими блюдцями.

У грунтовому покриві поширені зональні чорноземи південні малогумусні, глибокосолонцюваті в комплексі 3 темно-каштановими солонцюватими грунтами та азональними лучно-чорноземними й лучно-каштановими глейовими солонцювато-осолоділими грунтами і солонцями.

Природний рослинний покрив, внаслідок менших антропогенних навантажень, має значний ступінь збереженості. Він представлений типчаково-ковиловою рослинністю сухих та ковиловою і полиново-злаковою рослинністю ксерофітних та пустельних степів [4]; подових луків, включно 3 остепненими, а також рослинністю солонців, кіс та узбережжя Азовського моря.

Акумулятивні приморські, в т.ч. лиманні, низовини на лиманних, морських та сучасних морських відкладах мають плоску поверхню. Незначний ступінь прояву яружної ерозії в межах таких низовин зумовив відсутність тут розвиненої яружно-балковою мережі. Натомість, прояви просадкових процесів, підтоплення, заболочування зумовили ускладнення території просадковими формами (переважно блюдцями) і невеличкими озерцями та болотами, часто солоними.

Грунтовий покрив представлений чорноземами південними глинисто-піщаними та супіщаними, каштановими солонцюватими грунтами в комплексі з дерновими глинисто-піщаними та оглеєними супіщаними грунтами, лучними солонцями і солончаками.

У рослинному покриві поширена псамофітно-галофітна та галофітно-лучна рослинність узбережжя Азовського моря; пасовища на місці біднорізнотравно-типчаково-тирсової і різнотравно-типчаково-тирсової рослинності степів.

Флювіально-дельтові низовини плоскі, переважно слабохвилясті та хвилясті, на алювіальних, еолово-делювіальних та елювіальних відкладах, нерозчленовані. Внаслідок прояву еолових процесів, просадок порід, підтоплення територія відзначається наявністю кучугурного рельєфу (еолові горби). Важливим елементом ландшафтної структури $є$ так звані піщані арени, представлені масивами еолових піщаних горбів та дефляційних западин між ними. Виділяються сім великих арен: Каховська, Казачо-Лагерська, Виноградівська, Збур'ївська, Олешківська, Іванівська та коса Кінбурнська. Піщані арени розташовані на лівобережжі нижньої течії Дніпра між містом Нова Каховка та Кінбурнською косою $[2,6]$.

Також для території флювіально-дельтових рівнин, внаслідок прояву процесів просідання лесових порід та підтоплення, набули поширення просадкові форми: поди, степові блюдця, а також невеликі озера.

У грунтовому покриві представлені чорноземи південні та осолоділі, каштанові і темно-каштанові залишково-солонцюваті грунти у комплексі 3 чорноземними піщаними, лучними та дерновими азональними грунтами, пісками, солонцями i солончаками.

Природний рослинний покрив представлений 
різнотравно-типчаково-ковиловою рослинністю псамофітних (придніпровських) степів у поєднанні з березовими гаями, дібровами і насадженнями сосни, полиново-злаковою рослинністю сухих степів та приморською рослинністю пустельних галофітних степів у комплексі з рослинністю солонців та подовими луками.

Територія ландшафтного краю відзначається незначним ступенем розчленування балковими комплексами. Балки мають переважно похилі та покаті схили. Вони вироблені в еолово-делювіальних та елювіальних відкладах плейстоцену.

Грунтовий покрив балкових ландшафтних комплексів представлений чорноземами південними малогумусними, каштановими і темно-каштановими залишково-солонцюватими грунтами, місцями розораними, лучно-каштановими грунтами в комплексі з солонцями лучними.

Рослинний покрив представлений ковиловою та полиново-злаковою рослинністю ксерофітних, пустельних та типчаково-ковилових степів південних (сухих), частково збережених на схилах балок, і рослинністю солонців та солонцювато-солончакуватих луків.

Ландшафтна структура Херсонської області доповнюється ЛК річкових долин, акумулятивних морських кіс і пересипів, що мають значення інтразональних.

Річково-долинні ландшафтні комплекси області представлені у межах нижньої течії долин Дніпра та Інгульця і долиною малої річки Каланчак. Поперечний профіль річкових долин відзначається характерною асиметрією - 3 крутими правими схилами. Долини широкі, їх розширення, включно із заплавами, відбувається з півночі на південь. 3 просуванням на південь розширення заплав супроводжується поступовим їх переходом у лимани - Інгулецький та Дніпровський.

Для річкових долин можна виокремити комплекси перших-других, третіх-четвертих та п'ятихшостих надзаплавних лесових терас, що відзначаються плоскою та слабохвилястою поверхнею, ускладненою яружно-балковими та подовими комплексами.

У межах цих ландшафтних комплексів частково зберігся природний рослинний покрив, представлений ділянками типчаково-ковилової рослинності північних степів та різнотравнозла-кових засолених та солонцюватих, включно 3 плавнево-болотистими, луків, заростями верби i рослинністю солончаків (заплави, поди).
Ландшафти приморських кіс та островів представлені косами Бирючий острів, Тендрівська та островом Джарилгач.

Бирючий острів має довжину 24 км, ширину близько 5 км. Являє собою піщану приморську рівнину, в межах якої трапляються вали з черепашнику заввишки 0,7-0,9 м. Північно-західна частина острова знижена. Західний берег розчленований невеликими бухтами. Вздовж західного берега спостерігаються численні невеликі озера. Східний берег рівнинний. Природний рослинний покрив практично незмінений і представлений чагарниками: тамарикс, маслинка срібляста, шипшина, а також приморською літоральною рослинністю на азональних дернових оглеєних глинисто-піщаних грунтах і солончаках.

Коса Тендрівська витягнута у західному - південно-західному напрямі. Її довжина становить 65 км, ширина до 1,8. Коса утворена внаслідок дії процесів морської акумуляції й складається 3 піску та черепашки. Західна частина коси має “лопатоподібне” розширення. Правобережжя розширеної частини коси ускладнене береговими валами, між якими є невеликі озерця. Центральна частина коси має вирівняну знижену поверхню, ускладнену озерами. В південній частині коси поширені еолові горби та кучугури. Природний рослинний покрив представлений розрідженою галофітною трав'янистою рослинністю та чагарниками на слабосформованих дернових піщаних та супіщаних грунтах.

Острів Джарилгач має західно-південно-західне простягання. Довжина острова 42 км, ширина - 4,8 км. Відповідає плоским приморським та лиманно-морським низовинам 3 рівнинною нерозчленованою поверхнею. Територія острова відзначається наявністю невеликих морських кіс; на півдні простягається піщане пасмо. У грунтовому покриві представлені дернові оглеєні піщані, глинисто-піщані й супіщані та каштанові i темно-каштанові солонцюваті грунти в комплексі iз слабогумусованими пісками і солонцями солончаковими.

Природна рослинність представлена лучними, болотними та солончаковими формаціями, поширеними на півночі острова навколо боліт та невеликих озер; у центральній частині - сухостепова та лучна рослинність. У центральній та східній частинах острова є штучні деревні та чагарникові 
насадження з маслинки сріблястої та тамарикса.

Отже, на морських косах і пересипах представлена сухостепова, лучно-солончакова рослинність і рослинність пісків морських узбереж, пересипів i кіс у поєднанні з чагарникковими заростями. Певне поширення мають штучні деревно-чагарникові насадження (о. Джарилгач).

Значне засолення грунтів ландшафтних комплексів приморських, у т.ч. лиманно-морських, рівнин включно зі значним поширенням солонців і солончаків зумовили низьку їх придатність для сільськогосподарського використання, що сприяло значному ступеню збереженості природних ландшафтів.

Територія ландшафтного краю відзначається середнім рівнем сільськогосподарського освоєння. В iї межах, включно з частиною приморських рівнин, поширені орні угіддя, пасовища (збиті і сильно збиті), сади, виноградники. Наслідками господарської діяльності $є$ прояв і розвиток площинної та яружної ерозії, зсувів, просідань лесових порід, засолення грунтів. Разом з тим, прояв у межах краю процесів підтоплення, заболочуван- ня та засолення і зумовлена цим непридатність приморських ландшафтів для господарського використання сприяли частковому збереженню їх природної складової - ландшафтних комплексів морських кіс та островів та, частково, ландшафтів приморських рівнин.

Головним результатом проведених досліджень, як зазначалося вище, $є$ укладена карта ландшафтних комплексів на територію Херсонської області представлена на рис. 2. Робочим масштабом дослідження визначено - М 1:500000. Разом 3 тим, для забезпечення повнішого сприйняття представленого у статті опису ландшафтної структури регіону дослідження картосхема, що іiі ілюструє, представлена у масштабі М 1:850000.

\section{Висновки}

Різноманітність ландшафтів території Херсонської області потребує детального їх вивчення i відображення, зокрема, картографічними засобами з урахуванням результатів опрацювання матеріалів космічних знімань та польових досліджень безпосередньо на місцевості.

\section{References [Лimepamypa]}

1. Geographical encyclopedia of Ukraine. Vol. 3( 1993). Kyiv, 361-363. [In Ukrainian]. [Географічна енциклопедія України. Т. 3. Київ,1993. С. 361-363].

2. Marinich A. M., Pashchenko V. M., Shishchenko P. G. (1985). The Nature of the USSR: Landscapes and physical geographical zoning. Kyiv. [In Russian].

[Маринич А.М., Пащенко В.М., Шищенко П.Г. Природа УССР: Ландшафты и физико-географическое районирование. Киев, 1985. 222 с.]

3. Marynych O. M., Parkhomenko H. O., Petrenko O. M., Shyshchenko P. H. (2003). Improved physical and geographical zoning of the Ukraine. Ukrainian geographical journal, 1. 16-20. [In Ukrainian].

[Удосконалена схема фізико-географічного районування України. / О.М. Маринич, Г.О. Пархоменко, О.М. Петренко, П.Г. Шищенко. Український географічний журнал. 2003. № 1. С. 16-20].

4. Vegetation of the Ukrainian SSR. Steps, rocky outcrops, sands. (1970). Kyiv. [In Ukrainian]. [Рослинність УРСР. Степи, кам'янисті відслонення, піски. Київ, 1970. 428 с.]

5. Ukraine and Moldova. Ed. A. M. Marinich and M. Palamarchuk (1972). Moscow. [In Russian]. [Украина и Молдавия / отв. ред. А.М. Маринич и М.М Паламарчук. Москва, 1972. 440 с.]

6. Physical and geographical zoning of the Ukrainian SSR: materials on the natural and economic-geographical zoning of the USSR for agricultural purposes. (1968). Kyiv. [In Russian].

[Физико-географическое районирование Украинской ССР: материалы по природному и экономико-географическому районированию СССР для целей сельского хозяйства. Киев. 1968. 683 с.]

Стаття надійшла до редакції 08.06.2017 